\title{
What Some Students Found Challenging about Indireot Statement in Prose Composition
}

\author{
by James Eales
}

$\mathrm{O}$ e 'can hardly avoid controversy' when discussing prose composition (Pearcy, 1998, 35); the very idea seems to evoke only the extremes from a Classicist. Some avidly argue against it, labelling it a 'useless, archaic exercise' (Ball and Ellsworth, 1992, p. 55), some vehemently defend it, calling it 'an invaluable virtue in all areas of education' (Butterfield, 2013, p. 8). Others believe there are more important arguments to be made about Classics, comparing the argument about prose composition to 'litigating over property lines when the house is on fire' (Jacoby, 1994, xii, cited in Pearcy, 1998, p. 37). Despite this view, the debate about prose composition has recently been reignited. The recent publication in Politeia (Butterfield, Anderson, Radice \& Sullivan, 2013) demanded a new prose composition option for Latin GCSE in order to bring it in line with the current $A$ Level system and for students to 'obtain a higher level of linguistics familiarity and facility in Latin' (2013, p. 8). The DfE

(2014) has just published the guidelines to the reformed Latin GCSE, for first teaching in 2016, which does include recommendations for such an option.

This debate and its contemporary salience was my motivation for this research project. Despite this potential revival of composition in the GCSE, its uptake in A Level examinations is currently low (approximately one third of A Level Latin students each year choose the prose composition option) and from my experience in teaching in secondary schools prose composition has not lost the 'elitist' tag Ball and Ellsworth branded it with two decades ago (1989, p. 56).

Students themselves are not unsusceptible to such brandings and this research project was designed to test the students' own opinions on the usefulness of such an exercise for their Latin learning, and to investigate what they find particularly difficult about it.

'I am not going to say that writing is not one of the hardest tasks that language students face in learning a language. It is' (Gruber-Miller, 2006, p. 191). A classicist would be hardpushed to prove otherwise, and advocates for prose composition are all in sympathy. What they and opponents disagree on, however, is the outcome of the exercise: whether or not it improves reading Latin. It was this outcome that particularly motivated me with this research project. I practised prose composition in school at A Level but it was only at university when I discovered that it was unusual for me to have had so much

experience in it. My knowledge of grammar seemed to me to be all the better for it, and it had always been my belief that this, at least, was the product of prose composition. My second motivation came from an experience in my first placement school, when a Year 9 student (studying Latin two months into his second year) was asked to create his own Latin graffiti tag lines. This student was not incompetent at reading Latin, yet his attempt at translating 'I am chasing the beard' (a sentence typical of a thirteen year old) into Latin resulted in ego sum agitat barba. Evidently, this student could not apply the rules he knew about reading Latin to writing Latin. Gruber-

Miller was not wrong.

I therefore determined to explore the two following questions:

1) What do students of Latin find difficult about prose composition?

2) How much do students themselves believe prose composition benefits them?

It should be noted that, whereas in the past prose 'composition' in a classical language meant to compose freely, as a modern foreign language (MFL) student is expected to do, the term today is used merely to mean translation of sentences from English to Latin, and should be considered more as 'prose translation' (Butterfield, 2013, p. 8)

My research was carried out at an independent school. Pupils for entry in Year 7 and 9 are selected based on performance in an entry test based on Mathematics, English and Verbal Reasoning, and an interview. Sixth Form pupils also have an interview and are judged on GCSE performance.

Classics has a strong tradition in the school. Latin, Greek, Classical Civilisation and Ancient History are all taught. Latin is compulsory in Year 7 and 8 (the latter year is in sets); from Year 9 it is optional and students can make a further choice to continue to GCSE and then to A Level. 
The Year 12 class with which I conducted this research consisted of six students: three boys and three girls. They are high-achievers: all have ALIS scores of over 116, and so are considered to be well aboveaverage compared with other students across the UK. One student is studying Greek at A Level too. This same student and one other are also studying Classical Civilisation for A Level. All students in the class are predicted grade A or B for their AS exams which they will take at the end of the year. Only one student has been at the school since Year 7 (student C), two entered at Year 9 (students $\mathrm{A}$ and $\mathrm{D})$, and the remaining three entered in Year 12 from other schools.

\section{Literature Review}

\section{A Recent History of Prose Composition}

'The folly in the reform of institutions is to fix on an essential or a primary function ... Once one function has been given priority, all other considerations go by the board.' (A. Bennett, 1994, p. 352).

A large emphasis can be placed on nineteenth-century Classics when tracing the history of the issue of prose composition. This was largely because in the nineteenth century the 'attitude to the Classics was very different from that of the Renaissance' (Forrest, 1996, p. 1). Where Renaissance Classics was taught for rhetoric and style, nineteenth-century Classics was taught within a 'new linguistic discipline that resulted from the careful and accurate translation from and into the ancient languages. A classical education was now valued as a training in accuracy and precision' (Clarke, 1959, pp. 174-5). Thus composition in the ancient languages was considered to be as important as reading and translating them.

By the beginning of the twentieth century the convention of composition in prose and verse had gradually become established. Students of Classics were taught with the 'expectation that they would proceed in due course to university' (Forrest, 1996, pp. 2-3). This foundation can be attributed particularly to the Universities of Oxford and Cambridge, whose entry requirements for all subjects insisted on excellent knowledge of Latin and whose annual scholarship examinations were 'seen as of central importance in every classical sixth form' (Forrest, 1996, p. 3). Thus, the Classics were taught in the sort of schools which aimed to send students to Oxford or Cambridge universities with a singleminded linguistic approach.

However, the Second World War and subsequently the Cold War caused a surge in demand for science education. This endangered the position of Classics in schools. Oxford and Cambridge Universities abandoned the matriculation requirement for Latin O Level in 1960

(Stray, 2003, p. 4; Forrest, 2003, p. 44). As a result prose composition was no longer deemed as important a skill as it once was. Indeed, even as early as 1924, The Classical Investigation: General Report'sets as the central objective of secondary and university Latin study "the progressive development of ability to read and understand Latin"' (Carpenter, 2000, p. 391; Stray, 2003, p. 2) rather than the ability to write it. As a result, 1970 saw the introduction of the Cambridge Latin Course (CLC), whose main hypothesis was 'that a pupil could, from a skilfully designed course, develop within three years an intuitive grammar without the help of explicit grammar learning' (Sharwood Smith, 1977, p. 39). Forrest in his CLC review (1976) gives the CLC's two defining goals, the first of which is the most poignant in terms of prose composition, as: '1) comprehension of Latin for reading, 2) develop an understanding of the content, style and values of Roman civilisation' (cited in Forrest, 1996, p.121). This emphasis on reading Latin was designed to appeal to a wider audience than currently existed in Grammar Schools, and it left no room for prose composition. In one and a half centuries it could be said that the heart of Latin, in the interests of both utility and accessibility, had moved from composition to comprehension.

Today, according to the Cambridge Schools Classics Project (CSCP) website, over $90 \%$ of secondary schools in the UK that teach Latin use the CLC (CSCP, 2015). This means over $90 \%$ of schools that teach Latin teach it with the main aim to read it. It is the development of this widespread goal that has sparked debate among academics and teachers alike. If the main aim in Latin is to read Latin, then, in the words of Ashdowne and Morwood, 'the student who wants to learn an ancient language such as Latin never has to learn to produce a single word of the language' (2007, i). So, the critics say, learning prose composition is a waste of time: it could be better spent reading Latin, rather than writing (Ball and Ellsworth,1989).

\section{The Debate}

Saunders (1993) summarises the four main points of Ball and Ellsworth's report (1989) against the value of prose composition as follows:

1) Nineteenth-century scholars taught Classical languages as an 'intellectual discipline' because the languages as a means of communication were dying. This method is now outdated;

2) The teacher of Latin prose composition was a 'stereotypical elitist';

3) The main goal of learning Latin is to be able to read the language, not write it;

4) Prose composition exercises should be replaced by other exercises that reinforce recognition not production of grammar and syntax. (Saunders, 1993, pp. 385-6)

Ball and Ellsworth's article was received with much hostility by advocates of prose composition - Gilleland, for example, describes the paper as 'nonsense' (1991, p. 216). Newman (1990) and Gilleland (1991) wrote papers in direct opposition with their arguments, which led Ball and Ellsworth to update and clarify a few of their unsupported assertions (Ball and Ellsworth, 1992; Saunders, 1993). Saunders continued the attack in her 1993 paper, whose summary, which I have given above, will act as a guide through this review.

\section{Point 1: Nineteenth-century Classics}

The history of prose composition can be read in the introduction to this review. With respect to Ball and Ellsworth's 
point, Saunders (1993, p. 386) points out that they contradict themselves by suggesting that the prose composition method both 'arose' and was 'modelled' in the nineteenth century (1989, pp. 54-55). Clearly, composition did not begin in the nineteenth century, but its widespread use as a teaching method did (Clarke, op. cit.). What Ball and Ellsworth miss, however, is that the reason teachers in the nineteenth century (and earlier) used prose composition is the very reason that some teachers today like to use prose composition - for what they see as its value in improving knowledge of Latin. Saunders' comment is apposite: 'These teachers were following the precepts of Ascham, Vives, and generations of instructors who believed that prose composition would improve their students' knowledge of Latin' (1993, p. 387). Therefore, one cannot assert that prose composition is out of date merely on the grounds that nineteenth-century teachers used it as a means of an 'intellectual discipline'.

\section{Point 2: Elitism}

If there was any point in Ball and Ellsworth's paper that was met with the most criticism, it was point 2 , that prose composition 'became the favourite exercise of the elitist professors, since they knew they could exploit this complex pedagogical tool to humiliate and eliminate the less capable student' (1989, p. 56). Gilleland attacks this point, asking 'Where have the authors found such monstrous teachers of prose composition?' and suggests Ball and Ellsworth have 'set up a man of straw' (1991, p. 215). Ball and Ellsworth admit they were using a caricature and their own teachers taught prose composition with sympathy, but respond to this accusation that classicists cannot hide away from elitism, which has been rife over the last century:

'Our field must expunge this elitist attitude, an anachronism masquerading under the guise of excellence ... Our field has nothing at all to gain and everything to lose by denying this attitude exists.' (Ball and Ellsworth, 1992, p. 56).

To turn the argument towards Classics and elitism, however, is to turn away from the crux of the argument: how much does prose composition benefit students' understanding of Latin? Those who support prose composition do so for their belief in the benefits for the student, not for their own feeling of superiority.

And so I agree with Saunders that 'elitism is a behaviour... It springs from the character of a teacher. If some teachers of prose composition display "elitist attitudes," their behaviour does not reflect on prose composition, but only on the instructors themselves' (Saunders, 1993, p. 188).

\section{Point 3: The primary goal of Latin}

To understand how prose composition can benefit a student in Latin in school, one needs to know what the overarching aim for that student is. The goal to be able to read Latin has been omnipresent in pedagogical discussions, as Carpenter observes: 'The contemporary discussion of Latin Pedagogy has been marked by two characteristics: disagreement about methods but general agreement about the primary goal' (2000, p. 391). With this sentiment I now point to the quotation with which I began this view.

The primary goal of learning Latin to read Latin has caused other aims of learning Latin to fall by the wayside. As Pearcy reported: 'The seemingly innocent claim that the primary goal of studying Latin is to read ancient texts became enshrined in the lore of American classicists over seventy years ago' (Pearcy, 1998, p. 37). This matches the opinion of Carpenter (2000), who describes this primary learning aim as the 'dogma of Latin instruction' and continues that it 'has only been affirmed over the years and never once seriously challenged'

(Carpenter, 2000, p. 391). While Pearcy and Carpenter agree that this needs to be challenged, they differ slightly on what should be changed. Carpenter argues that this primary learning aim is out of date and needs replacing: 'The modern societal perception of higher education as a training ground for future workers has necessitated changes in Latin curricula which make this goal unachievable today: the 'primary objective' of the Classical Investigation Report no longer meets the needs of our students and teachers' (Carpenter, 2000, p. 391). By contrast, Pearcy believes that other learning aims of Latin need to be brought to full awareness again: 'Like the belief that the sole purpose of forests is to produce lumber, the belief that the sole purpose of studying Latin is to read Latin has led to a clear-cutting of the curriculum and ravaged environments' (Pearcy, 1998, p. 38).

Goodson makes a good case for reading Latin in the classroom, stating that 'it is not necessary for pupils to understand every word or grammatical construction of a passage in order to learn from it and enjoy it' (Goodson, 1997, p. 8), but the importance placed on the primary goal of reading Latin needs to be questioned. For, by the time that a student is expected to read real, unabridged Latin, he has reached a level where only a very small percentage of students have continued to study the subject, as has been observed by Carpenter in American college students (Carpenter, 2000, p. 392). So, it is argued, if the majority of our Latin students in schools are not accomplishing the aim of reading Latin at this level, it is worth considering other learning aims for studying Latin as well. In this case, prose composition might aid our students in the pursuit of these other learning aims.

What, then, are the other aims of learning Latin? While there have been countless papers by academics defending the subject, perhaps the most pertinent publication answering this question is the recent DfE (2014) publication for the new Latin GCSE for first teaching in 2016. Before outlying the structure of the new GCSE, in which Latin prose composition is an option in the language exam, DfE sets out the subject aims and learning outcomes:

'GCSE specifications in ancient languages should provide a strong foundation in linguistic and cultural competence and break the boundaries of time and space and access knowledge and understanding of the ancient world directly through reading and responding to its language and literature' (DfE, 2014, p. 3).

It elaborates on these aims, namely, understanding and interpreting ancient literature, and developing critical and analytical skills. Further aims are set out, in which students are encouraged to

- develop insights into the relevance of studying Classics; 
- deepen their understanding of English;

- relate Classics to other disciplines;

- develop research and analytical skills which will empower them to become independent students and enquirers (DfE, 2014, p.3).

To sum up, there seems to be general agreement about the following aims of learning Latin:

1. Reading and understanding Latin;

2. Critical evaluation of literature;

3. Improving knowledge of English;

4. Developing and improving analytical skills.

Point 4: The value of recognition and production

The DfE (2014) recommends the inclusion of a prose composition option in the GCSE exam and states that 'the content of the GCSE specifications in ancient languages must fully reflect the aims and learning outcomes' (DfE, 2014, p. 4). And so, in this respect, it is worth discussing whether the new prose composition option can help the students achieve the four aims of studying Latin (as given above).

The production of Latin, protagonists claim, helps the recognition and reading of Latin (Aim 1). 'I concur with Ball and Ellsworth's third assertion, that reading is an active process which can be learned without writing Latin.

However, this does not mean that reading is not improved by writing' (Saunders, 1993, p. 388). Saunders later quotes the school textbook ecce Romani as an example of this: 'Writing skills should not be neglected. They will contribute greatly to the achievement of (reading Latin)' (Saunders, 1984, p. 5).

Whereas nineteenth and early twentieth-century prose composition placed an emphasis on the imitation of classical authors (Postgate, 1934, p. 1), today the emphasis in schools is to enhance the comprehension of Latin. Bennett and Bristol observe that the teaching of composition was not, in their day, realising its prime purpose: 'The field may be partially cleared by stating, first, what it does not accomplish, at least in the school, namely, an ability to write continuous Latin with fluency and ease. Whatever be the purpose of the study, it cannot be that' (Bennett \& Bristol, 1903, p. 960). Understandably, the most vocal defence of prose composition achieving Aim 1 can be found in the textbooks that provide auxiliary prose composition exercises themselves. Taylor (2003) in the preface of his Greek textbook states: '[English-to-Greek exercises] are an invaluable means of clarifying and reinforcing students' understanding of the language,' and the introduction to Ashdowne and Morwood (2007) states: 'Practising the language in this way helps to fix constructions and vocabulary in the mind, so that a student can read texts with greater fluency, accuracy and therefore enjoyment.' However, while these authors offer opinions on the benefits of prose composition, they offer no solid evidence. The only evidence that can be found to support any argument is Ball and Ellsworth's reference to a scientific study claiming that writing and reading languages are independent skills that only interact with each other (Rivers, 1981, pp. 266-268, cited in Ball and Ellsworth, 1989 and 1992). For more academic approaches to the support of prose composition, see also Gilleland (1991, p. 216), Pearcy (1998, p. 35) and GruberMiller (2006, p. 191) who have been quoted throughout this review.

Nevertheless, even these do not provide supporting evidence.

Few students go on to read any unabridged Latin (Carpenter, 2000, p. 392). To my mind, then, this raises the question originally posited by Duckett: 'May we not think we have something to offer to the student of Liberal Arts though he never means to be a Latin classicist?' (Duckett, 1922, p. 437). That is, he suggests that studying Latin can achieve other aims. By way of illustration certain writers argue for prose composition as an aid to achieving Aim 4. Earlier writings on the profits of prose composition focus on the idea of 'moral training' (The Classical Investigation: General Report, 1924; Nairn, 1925). This is a little farfetched and, perhaps, the catalyst for the 'elitism' tag that Ball and Ellsworth discuss. But, of course, what Duckett is implying is mental training, which might achieve Aim 4. There are many examples of academics supporting the use of prose composition as brain training (Mitchell,1912; Nairn,1925; Carpenter, 2000). Mitchell quotes a certain Professor Kellogg: 'We wield in Latin grammar and prose composition an implement as keen as mental arithmetic' (Mitchell, 1912, p. 26). Mitchell, in fact, describes the 'aim [of prose composition] as more serious and more important [than reading Latin] - reasoning power, memory, judgment, invention, resourcefulness' (Mitchell, 1912, p. 27). More recently, Carpenter has expressed the same sentiment as Duckett: 'Students may never be able to speak or write in the language, or even easily read the literature. They should, however, have developed analytical thinking skills which will in turn be applicable to other pursuits' (Carpenter, 2000, pp. 394-5).

Therefore, prose composition has been argued to have the potential to help students not only in the widely accepted (although recently questioned) primary learning aim of reading and comprehending Latin (Aim 1), but also in Latin's other learning aims: developing and improving analytical skills (Aim 4).

\section{Composition in the classroom: ancient and modern}

An issue prose composition has faced is the 'traditional' approach, which can be described as the 'translation into decontextualised sentences or paragraphs from the textbook' (Gruber-Miller, 2006, p. 214, n.1). Attention has been paid to this over the years. In the UK possibly the most popular modern text book which advocates prose composition (Taylor (2003)) still contains such sentences. Earlier attempts to alter this approach include Postgate (1934) who revised his edition to include 'passages dealing with scenes of actual life, which should prove of especial value in counteracting the impression so fatal to progress that Latin is a language of the dead.' There have been several reports on new ways of teaching prose composition that have much to recommend. Davisson (2000), Fogel (2002) and Gruber-Miller (2006) all focus on using prose composition to learn the grammar and syntax of the language but by reinforcing the nature of Latin as a communicative language.

This sentiment can be traced back to Nairn: 'If we believe that Latin is alive, we shall study it with keener interest' (Nairn, 1925 , p. 6). It is worthwhile therefore to 
pay attention to the methods of modern foreign language learning. Harklau (2002) insists that 'writing to communicate reinforces the acquisition of language' and Gruber-Miller (2006) writes a very good and up-to-date article on the parallel between reading and writing with many modern and relevant references, which refute the scientific study mentioned in Ball and Ellsworth almost two decades before. There has, however, been much debate in the modern foreign language sphere. There has been a great deal of shifting and changing between the idea that grammar is and is not useful to learn. Krashen (1981), for example, argued that grammar learning is short-lasting and does not help in a student's overall competence. But what a classicist has to remember is that Classics lacks the need for all three skills: reading, writing, and speaking. Classicists need at most the first two. Lee (1963, p. 23), for example, argues that, if just for the sake of making the most of the skills that are available, classicists should attempt writing as well as reading. But modern foreign languages students need to be able speak the language, which is learnt by use rather than by rote learning the grammar.

\section{In summary}

Pearcy (1998) considered the dogma of Latin instruction, but the literature omits what is sadly the dogma of education in the UK as a whole: examinations. None of the national UK Latin examinations have a compulsory prose composition element. Thus, as Ashdowne and Morwood said, no student has to have learnt to produce a single word of Latin $(2007$, i). What students learn in UK schools is dictated by the examination boards, whose remit is in turn dictated by government. The recent publication of the DfE guidelines for GCSE Latin and ancient Greek (2014) is therefore of intense interest. It is a fascinating time for the pedagogy of Classics and it will be interesting to see the impact of prose composition on its introduction into GCSE examinations. But, while uptake of prose composition in schools is affected by its presence (or absence) in examinations, the notion of its difficulty affects it too. There is much discussion but little evidence by way of research to back up opinions. I therefore propose to contribute to these discussions by providing a small amount of evidence for what it is about prose composition that students find difficult.

\section{Methodology}

My research can be considered to have two aims, which require two different methodological approaches:

\section{1) What do students find difficult about prose composition?}

\section{2) To what extent do students believe prose composition benefits them?}

The first aim of my research can be placed into the category of a case study. The analysis of their responses to the prose composition exercise also complies with the aim of a case study as 'to portray, analyse and interpret the uniqueness of real individuals and situations'(Cohen, et al., 2007, p. 85).

However, the second aim of my research does not fit so easily into the bracket of a case study. This class is not often taught prose composition, and while the class is allowed to make their own choices about whether to take the prose composition option in their examination, the general assumption is that they will not opt to do it. Therefore, by preparing the class for the prose composition exercise, and indeed giving them the exercise, I have partially altered the way they otherwise are taught. As such, one can label this research partly as action research whose aim is 'to plan, implement, review and evaluate an intervention designed to improve practice' (Cohen et al., 2007, p. 85). Therefore, my research project can be considered a case study followed by an element of action research.

\section{Observations and Latin-to-English}

Before I could give my class a prose composition exercise, I had to prepare the students for it in three lessons over seven days. This was, to begin with, a reintroduction to indirect statements with simple Latin sentences to translate and a discussion of the tenses of infinitives. The further the class progressed, the more difficult the examples became. In the second lesson I gave them Latin-toEnglish questions to translate individually so that I could assess how much they could recognise and understand the construction. In this way I could compare their competence of indirect statement in Latin-to-English and their competence of the same construction in English-toLatin. By the third lesson, we had moved onto the more complex examples of indirect statement such as the use of fore $u t$. After each lesson I wrote observations on how the students reacted and how they found it. These observations and the Latin-to-English exercise help achieve the 'multiple perspectives' recommended by Wilson (2009, p.120) in order to improve the validity of the results.

\section{Questionnaires}

My second main data collection method was questionnaires. I prepared the questions in a way that would make analysing the recorded data easier and planned it by using a matrix table. However, one must note that with such a small scale of information, I could not use the data to make generalisations. I decided against individual interviews, despite the data size being manageably small. The class has been taught by me for two months and is familiar with my method of teaching and my interests in Classics. Thus the students were likely to know that I am not impartial to using prose composition as a teaching method (besides, I was using a small amount of prose composition to prepare them for this research, anyway). So the 'intrusiveness' of an interview vis-a-vis (Sapsworth \& Abbott, 1996, p. 318) might have left them uncomfortable with giving their own opinions on prose composition, which might have skewed and compromised the validity of the data. While the same issue persists with the completing of questionnaires, the factor of anonymity I believe justifies this decision.

\section{Audio recording and prose composition}

In order to keep the number of variables to a minimum, I decided to use only one type of construction in the prose composition. This was indirect statements, which in my experience can often confuse 
students, especially with regard to the tenses of the infinitives. The exercise was a hybrid of a few exercises in Taylor's text book Latin Beyond GCSE (2012). The exercise was done in pairs, with each pair at a time in a spare room. Their discussions were recorded on a mp3 recorder, so that I could write up the transcripts and analyse them. They were invited to speak aloud any thoughts they had. The pairs were organised so that the most able (student B) worked with the least able (student A) in order that conversation could be induced. It was hoped that student A would talk through his inhibitions. Thus, the second most able and second least able (student $\mathrm{F}$ and E respectively) were put together and the middling two (student $C$ and D), for similar reasons. It also worked out that each pair had one male and one female, so that if any difference in gender was observed, it could be noted. These pairs I labelled Group 1 (students A and B); Group 2 (students C and D) and Group 3 (students $\mathrm{E}$ and F). Student F was absent during the experiment period.

\section{Results}

The audit was used mainly to establish the students' confidence. Confidence in English-to-Latin composition was, understandably, lower than Latin-toEnglish in all cases. The most confident pupil (C) proved an anomaly as all four other participating students had an average of lower than 3 for all syntax of prose composition, thus falling in the 'needs some work' category. Student E rated all his prose composition syntax as 1, 'needs a lot of work'. Student E's confidence in language overall was low, including knowledge of vocabulary and indirect statement; he labelled his strength as literature, and has always been lacking confidence in his language skills. Student C's confidence was very high in manipulating all forms of syntax.

None of the students said that they were going to be doing the prose composition in the exam. Figure 1 is a graph of the students' mean confidence in syntax as given in the audit (appendix A), where 5 is 'excellent', 4 is 'good', 3 is 'satisfactory', 2 is 'needs some work' and 1 is 'needs a lot of work':

Answers to what the students found most challenging about prose composition

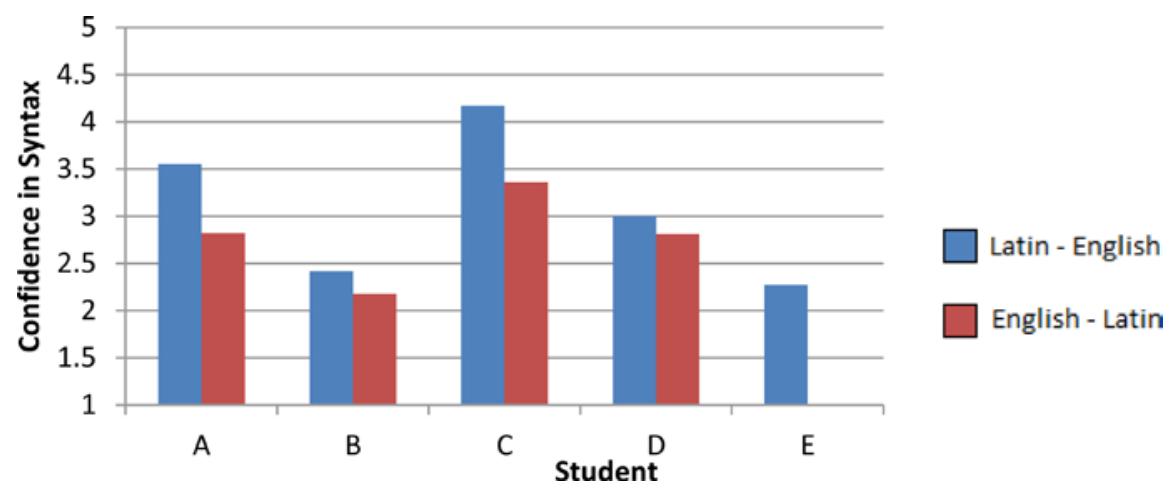

Figure 1.|Confidence in Syntax in Latin to English and English to Latin. (question 7, appendix B) were broad and emphasised their lack of confidence in grammar from English-to-Latin. All agreed that formation of noun and verb endings were the most difficult, with a further two also suggesting weakness in vocabulary. Interestingly, student B also suggested word order as being the most difficult part of prose composition. Figure 2 shows what students believed was most difficult about prose composition, prior to the exercise.

\section{Latin-to-English}

Considering the class had previously practised indirect statements, students A, $\mathrm{C}$ and $\mathrm{E}$ still translated the tenses of the infinitive inaccurately. Student A, the weakest of the group, translated all indirect statements literally with an English infinitive, e.g.:

\section{Q3 (Appendix A): femina negat se} quicquam de consilio scire. Student A's translation: The woman denied herself to know anything about the plan.

This, of course, is literally correct and illustrates the student's understanding of the use of accusative and infinitive. However, the non-idiomatic expression betrays discomfort about the construction as a whole. Pupil B, the strongest of the class, and student D, both of whom lack confidence, translated pleasingly well (Appendix A). The accuracy of their scripts, however, did nothing to relieve me of my fear for the prose compositions from students A, C and E.
Figure 3 shows the frequency and type of mistake in the translation of Latin-to-English indirect statements made by each student.

The most common mistake was translating the wrong tense of the infinitive. Three of these five mistakes were from the same infinitive in question 2: audivistine illos captivos effugisse? Students B, C and E all translated as 'Did you hear that those captives fled / escaped?' This is more of a mistake in using the English infinitive in indirect statements than in recognising the tense of the Latin infinitive. So, overall one might say that translating the infinitive in indirect statement did not cause too many problems.

\section{Prose composition}

The overarching theme in the prose composition with all the groups was inaccuracy with the more 'intricate' syntactical details. For example, conjugation of verbs (Group 1: credemus for credimus; Group 1 and 2: defenderi for defendi); gender of nouns (Group 1 and 2: hoc legem for hanc legem; Group 3 missed 'hanc' out entirely); agreement of the participle in periphrastic infinitives (No groups made missam esse agree with epistolam; Group 3 had many 'nominative' infinitives). Figure 4 shows the type and frequency of mistake in the English-to-Latin indirect statements:

Despite appearances in the table, vocabulary was not a particular issue for the students when they were attempting

\begin{tabular}{|c|c|}
\hline Aspect mentioned by students & Frequency (5 students) \\
\hline Accidence & 4 \\
\hline Vocabulary & 2 \\
\hline Recognising Constructions & 1 \\
\hline Word Order & 1 \\
\hline
\end{tabular}

Figure 2. What students think is most difficult about prose composition. 


\begin{tabular}{|l|r|r|r|r|r|r|}
\hline Mistake & $\begin{array}{r}\text { Student } \\
\text { A }\end{array}$ & $\begin{array}{r}\text { Student } \\
\text { B }\end{array}$ & $\begin{array}{r}\text { Student } \\
\text { C }\end{array}$ & $\begin{array}{r}\text { Student } \\
\text { D }\end{array}$ & $\begin{array}{r}\text { Student } \\
\text { E }\end{array}$ & Overall \\
\hline Tense of Infinitive & & 1 & 1 & & 3 & 5 \\
\hline Vocabulary & 1 & & & 3 & & 4 \\
\hline Non-idiomatic & 4 & & & & & 4 \\
\hline Tense of Main verb & 1 & 1 & & 1 & & 3 \\
\hline Construction & 1 & & 1 & & & 2 \\
\hline $\begin{array}{l}\text { Voice of subordinate } \\
\text { verb }\end{array}$ & 1 & & & 1 & & 2 \\
\hline Number of nouns & 1 & & & & & 1 \\
\hline
\end{tabular}

Figure 3. | Number and characteristic of mistakes made by each student in translation from Latin into English of Indirect Statement sentences.

\begin{tabular}{|l|r|}
\hline Mistake & Frequency \\
\hline Vocabulary & 9 \\
\hline Formation of infinitive & 6 \\
\hline Case with preposition & 2 \\
\hline Periphrastic infinitive agreement & 2 \\
\hline Noun gender & 2 \\
\hline Formation of present tense (thematic vowel) & 2 \\
\hline Construction & 1 \\
\hline Person ending & 1 \\
\hline Tense of main verb & 1 \\
\hline
\end{tabular}

Figure 4. |Frequency of mistakes in the English-to-Latin translation.

the prose composition. There were only four times when any group could not think of the word at all: defendi (Q3; group 3); antea (Q4; group 2 and 3); and mutatum iri (Q5; group 3). Group 3 also made three other mistakes, which were all Latin words that made sense in context: argentum for pecuniam; scimus for putamus and venturus for adventurum.

The most prevalent issue in doing the prose composition exercise was confusing the grammar. Figure 4 suggests that vocabulary was the biggest cause for error, when actually closer inspection of the transcripts shows that students tended to talk themselves into confusion. See for example lines 4-19 from Group 1 as students A and B discuss Question 1 'The boy said that he had found the money in the wood:

\begin{tabular}{|ll|}
\hline A: & Said bimself to have done. \\
B: & So that's. That's perfect active \\
& infinitive, or is it, yeah perfect \\
& active so to have found. \\
A: & Yeah. \\
B: & So yeah 'to find' is invenio. \\
A: & So invenisse? \\
10 B: No, that's present active. \\
A: & No the -isse endings, no no \\
& no, present is invenire, then \\
& invenisse is the perfect, correct \\
& me if I'm wrong.
\end{tabular}

B: OK, what is, what's perfect, no what's the present passive ending?

A: That's - ari instead of -are.

15 B: So you think it's -isse?

A: I think it's -isse.

B: Does it have invenisset or is it just invenisse?

A: If it was in the subjunctive...

B: Oh then it's not that.

Notice how student B begins to derail when they come to forming the infinitive. She has correctly identified that the perfect active infinitive is needed (line 5), but begins to confuse the formation by suggesting a) -isse is present active infinitive (line 9) and b) they need to know the present passive ending (line 11), which clearly is surplus to requirements. She seems to be in a fluster, which is further emphasised by her asking whether invenisse should have a person ending (line 17). Had student B been in class translating an unseen, for example, she would without doubt know that an infinitive does not have person endings. It is fortunate that student A was there to answer her questions accurately and confidently to keep their answer on track.

This was where Group 2 fell down: neither student $C$ nor $D$ was able or confident enough to stay composed and focus on what they knew. See, for example, lines 41-44 and 61-72 when discussing Question 3: The messenger promised that the king would soon arrive:

41 C: Ohpromise...

D: Oh and we have to use the subjunctive for this ... we have to use-

C: Ok, promittit, is that the perfect? promiti ...'he promised'.

D: Oh and this is the bit where you have to use fore $u t$.

$61 \mathrm{C}:$ advenio.

D: But, we need it to be... in the future subjunctive.

C: In the active?

D: Yeah future active subjunctive.

65 C: Ahh, that's just. . you see, it's just, it's just not worth it.

D: It goes -tur doesn't it?

C: Does advenio go to -tur?

$\mathrm{D}$ advenetur? In the subjunctive.

C: Oh yeah, advenetur. No, but then you've got esse haven't you? Or is that with the subjunctive or not?

70 D: Yeah but that's a different type of subjunctive isn't it, like esse is the-

C: advenetur, we'll go with advenetur?

D: Yeah.

Just like student $\mathrm{B}$ above, student $\mathrm{C}$ is confusing one grammar rule with another. She is aware that some types of future indirect statement take fore $u t$ and the subjunctive. She is also aware that verbs of promising take future infinitives in indirect statement. However, she is mixing the two and suggests the sentence requires fore $u t$ plus future subjunctive. Although there technically is no future subjunctive, the class had recently done indirect questions where a type of future subjunctive is needed. This may be the reason why they do not reject such a possibility for this sentence. Of course, their confusion is exemplified by their composing of the impossible advenetur (lines 67-69).

All examples of this confusion were when forming the infinitive; the rest of each sentence was translated with little difficulty. Further examples of this may be found in lines 35-50 of Group 1 
translating Question 2: We think that the city is being well defended:

35 A: 'Is being'-

B: 'Well defended' is- it's passive of defend, so defendar? 'That doesn't look right...

A: Yeah cos it's present. So it would be.

B: Defendari. What's 'well'?

A: Bene.

40 B: bene.. putamus urbem. does... defendari doesn't look right though. It doesn't look like it agrees with urbem.

A: It doesn't have to agree though, in this case since it's a passive present... it would have to agree with, if it was, like, in passive like putamus esse urbem, like, we.. or I dunno.

B: So you think it's putamus urbem bene defendari.

45 A: putamus urbem bene defendari..

B: Is it definitely -der?

A: I put something down like that.

B: I think it's -deri.. is it -dari or -deri...

A: I think-deri.

50 B: Yeah let's just go with that. So putamus urbem bene defenderi.

Here they are acutely aware that passive infinitives end in $-i$, but do not consider the possibility of third conjugation passive infinitives. This is the only difficulty they had with the question, getting everything else correct. Compare Group 2's translation of this sentence at lines 25-33:

25 C: Which we have to add well defended... defend is your verb.

D: Defend and then it's the present passive.

C: defendum...

D: It's defenderi, wouldn't it be?

C: Oh ok, yeah, defender? Ok, well put that at the end.

30 D: What conjugation is it, is it third?

C: I don't know, defendo... No it's first, it's like porto.

D: Yeah ok that's fine.

C: defenderi... and ermm well... er bene?
It is interesting to see the two groups have a very similar conversation. As always, it is the infinitive causing the problems. Notice how when they agree (wrongly) that defendo is the first conjugation, they attach the suffix of the second conjugation anyway.

See also Group 1, lines 61-70, translating Question 4: The old man said that the letter had been sent previously:

61 A: The old man said that the letter had been sent previously. senex, what's 'letter'?...

B: epistulam... had been sent... to have been sent, so it's perfect passive. What is-?

A: mitto so-

B: Missus

65 A: missum esse.

B: So senex dixit-

A: Does it actually take endings? Like. . .

B: antea...before.

A: Or does it have to be [indiscernible]?

70 B: misum esse... good.

The students correctly identify the form of infinitive needed and give the correct form (lines 62-65). However, they do not make it agree with epistolam. Student A considers this at line 67 and 69, but does not have enough conviction to consider it further when student B dismisses it. Notice how Group 2 correctly identify the type of infinitive but attach the wrong piece of syntax, as in previous examples. See lines 79-90:

C: Ok so we know we've got had been sent... that's perfect. . .

80 D: Is it the... but does it take... when it's in the passive erm-

C: It's perfect passive.

D: It's perfect passive, so does it go iri?

C: No that's future passive... No that's, [indiscernible], it goes esse for the future... no it probably does go iri doesn't it?

D: Yeah I thought that was the future.

85 C: epistulam... because you know you've got the participle plus 'to be'. So, yeah, so I think it's iri.

D: Yeah epistulam.
C: Had been sent... mitto is 'I send'.

D: missus, so its missum iri.

C: missum iri.

90 D: But it has to agree with epistulam.

The two students are completely confusing themselves with the terminology and the different tenses of the formation. They correctly identify the infinitive is perfect passive (line 81), but student $\mathrm{D}$ confuses future passive, which uses $\mathrm{ir}$, with the perfect passive (line 82). Student $C$ corrects him initially (line 83) but confuses herself by thinking esse is used with the future infinitive (which is, of course, correct if considering the future active; the student can perhaps be forgiven for confusing this!). This leads her to agree that iri should be used, because she feels it is the only other option. This conversation is particularly interesting considering how easily they translated the perfect active infinitive 'to have found' in question 1 (see line 10, appendix $G$ ).

Unsurprisingly, Group 2 confuse the future passive infinitive in question 5 : We believe that this law is going to be changed. Lines 115-141:

C: $\quad$...is going to be changed. So that's fore ut isn't it?

D: No, oh is it verbs of believing, it is $v$ - like I know promising is definitely... is definitely one that takes subjunctive. But I don't know whether this one is.

115 C: Erm, ok well we might as well not, let's not do it in subjunctive. No we might as well because is going to be means it is the case that so it will be fore ut.... erm to be changed. Change? What's Latin for change?

D: mut- muto, isn't it? Like mutat.

C: Like mutant?

D: Yeah.

C: $\mathrm{Ok}$, erm, now erm, future passive is all we need and then we're finished. Future passive subjunctive.

120D: muto, mutare.

C: Future passive subjunctive of muto. 


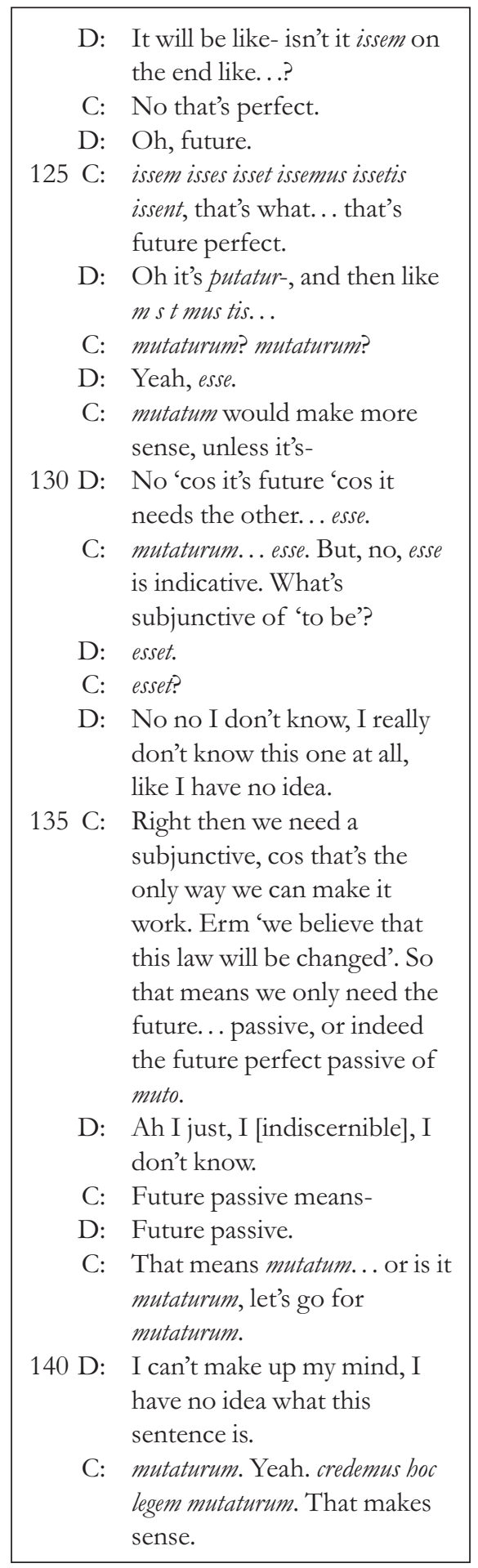

Student C correctly identifies that fore ut could be used here. But as in Question 3 (lines 41-44 and 61-72), they confuse indirect statements with future infinitives and fore $u$ plus subjunctive. They eventually decide to try the subjunctive (line 115), opting to use the future passive (line 119; a consequence of confusing verbs of promising taking the future infinitive). Again, student D confuses his grammar by suggesting -issem would be future passive subjunctive (line 122). Clearly student $\mathrm{D}$ recognises the ending as a subjunctive, but gets confused. Student $\mathrm{C}$ then wrongly labels this as future perfect (line 125). After further confusion, note how student $\mathrm{C}$ believes that the subjunctive is 'the only way we can make it work' (line 135). Just as they plumped for iri in the previous example, their confusing discussion has left them feeling backed into a corner and with only one option. By the end of the question, they finish with simply mutaturum for what should be either a future passive infinitive or present passive subjunctive (with fore $u t$ ). This was an attempt at a 'future passive subjunctive' yet they have forgotten even to write fore $u t$ (despite discussing it at 113-115).

Their misguided conversation left them simply giving up and going for whatever form of the verb they had at the time (line 141). Giving up was a pattern throughout the prose composition of all groups. See Group 1 line 50:

45 A: putamus urbem bene defendari...

$\mathrm{B}$ : Is it definitely -der?

A: I put something down like that.

B: I think it's -deri.. is it -dari or -deri...

A: I think-deri.

50 B: Yeah let's just go with that.

By this time, the students have lost confidence in getting the correct form of the infinitive and plump for something. This trait was particularly seen in Group 2, seeing as they perhaps got the most confused and felt the highest need to move on. See, for example, lines 71-74 when trying to form a 'future active subjunctive' and 91-107, when they cannot think of the word for 'previously':

71 C: advenetur, we'll go with
advenetur?
D: Yeah.
C: nuntius promissi fore ut rex mox
advenetur.
D: That sounds about right. It's
probably wrong, but that's
fine.

Student $\mathrm{D}$ here admits that it is probably wrong but they have no alternatives so stick with what they have.
C: Errm previously... before, po-.. erm.. propter... no that's not before. Before... post... post is before?

$\mathrm{D}: \quad \pi \rho \mathrm{v}, \pi \rho \mathrm{\imath} v$ is before isn't it? No, that's Greek, sorry I'm confusing it.

C: Erm before?

D: Previously?

95 C: What's before, as in a prepositional sense?

D: pro.

C: pro-yeah, we'll use that.

D: No that's Greek... no I swear it. .. is it Latin as well?

C: We'll go for pro.

100 D: I don't know, I'm confusing the two of them now.

C: dixitpro, yeah but it doesn't make sense saying epistulam pro misum.

D: No no no, it just-

C: pro, ok senex dixit pro epistulam.

D: No no no, that just doesn't work.

$105 \mathrm{C}$ : Yeah that makes sense. If Cicero changed his order of letters...

D: It's fine, no but we can, 'cos normally when it's like putamus, it will probably go at the end, like. .

C: If he changes his word order willy-nilly then I don't see why we can't.

This conversation epitomises all the struggles Group 2 went through when doing the prose composition. Student D confuses Greek words with Latin, student $\mathrm{C}$ uses a preposition for an adverb and by the end the students have perhaps forgotten to take the exercise completely seriously. Student D is aware at line 104 that what they have produced is nonsense, but student $C$ persists and keeps what they know is wrong. Another example may also be found when they are trying to find the future passive subjunctive of muto in question 5, lines 139-141:

C: That means mutatum... or is it mutaturum, let's go for mutaturum.

140D: I can't make up my mind, I have no idea what this sentence is.

C: mutaturum. Yeah. credemus boc legem mutaturum. That makes sense. 
By this stage they have spent a long time discussing this, and judging by student $\mathrm{D}$ at line 140 have got so confused that they are pleased to just complete it.

It seems, then, that the students are very capable of identifying which infinitive to use from the English, but when it comes to forming the infinitive in Latin they get confused about which endings to attach to which forms. This confusion leads the students to eventually plump for something which they do not have confidence in because they have nowhere to fall back to in order to solve the answer.

Before analysing these results further, I shall briefly discuss a few more things that arose from the transcripts.

1. Students tended to have an instinctive feel as to whether their Latin looked correct. See, for example, lines 36 and 40 when student A states that 'defendari doesn't look right', or line 74 in group 2 when student D professes that their sentence 'sounds about right', and also at 104 when student D knows instinctively that senex dixit pro epistulam 'just doesn't work'.

2. Students often remembered the initial sounds of a piece of vocabulary before remembering the word as a whole. See, for example, group 1 lines 28-30:

\section{B: Erm ok so we think - \\ A: Errm...}

30 B: Er...puo?puto?

Consider also, lines 91-92 when group 2 cannot remember 'previously' and have led themselves down the wrong path with the initial sound $p$-:

91 C: Errm previously...before, po-.. erm.. propter... no that's not before. Before... post... post is before?

D: $\pi \rho \imath v, \pi \rho \imath v$ is before isn't it? No, that's Greek, sorry I'm confusing it.

See also for group 1 line 20:

B: Oh then it's not that. So to have found the money, what's that?

20 A: pecun-..pecuniam?
For group 2 see line 37 and 116:

37 C: Ok we've got ten minutes to do the last three... The messenger. $n-$...

$\mathrm{D}:$ nuntius.

115 C: $\quad$... erm to be changed. Change? What's Latin for change?

D: mut- muto, isn't it? Like mutat.

3. Sometimes the students remembered vocabulary in inflected forms rather than the initial form in a vocabulary list. See group 1 line 20 above as student A remembers pecunia in the accusative form, line 72 ('That this law, isn't it lege, legum ?') where lex is remembered in the ablative first. Group 2 also does this at line 109:

$110 \mathrm{C}$ : We believe... erm, credimus... credo... is credo like porto? It would be credamus. crede- No it's credes - it's credes- you believe, so it's credemus. credemus... erm... that this law... legem is law.

The student remembered 'credimus' before stripping it to its first principal part. This eventually caused the error because the student remembers future credes to assure himself it is a second conjugation verb and thus should be credemus instead of credimus.

\section{Questionnaires after prose composition}

Figure 5 shows what the students thought was least and most difficult in the prose composition exercise:

Clearly it was the construction that caused the most difficulty. Vocabulary did not cause much of a problem.

\section{Findings and Analysis}

Firstly, students are not confident in their ability to translate English-to-Latin. This is hardly surprising considering they are not taught to do so and do not practise it. And so, what students find most difficult about indirect statement in particular is the formation of the infinitive. Seeing as they have never had to form infinitives before, or form indirect statements, they have not needed to know exactly how they work. Students B and D, in particular, showed how well they could recognise and translate them in the Latin-to-English translation, but were not nearly so accurate when doing English-to-Latin. The students were able to tell which tense was needed from the English but then could not translate that into Latin. In general there was a lot of confusion in terminology and attaching the right grammar to the right type of indirect statement: they were familiar with the different forms but could not put them in the right place. It was clear that they were accomplished at reading Latin but not so at writing it.

It should also be noted that mistakes other than formation of the infinitive were mainly from poor knowledge of the intricate details of Latin words, for example, they were not able to recall a noun's declension and gender or a verb's conjugation and principal parts. Forming simpler clauses, such as subject-verbobject, caused no problems and may come as a result of their experience in Latin. They have not had as much experience of indirect statement in Latin as they have had of simple clauses.

Finally, it is worthy to note how impressive student A was at prose composition. In my observations I have noted how he is often able to recite endings if required. And, in fact, students have looked to him in the past to recite them when they are stuck in translation. He was, however, before the research labelled as the weakest in the group and for the record has the lowest ALIS score of the class. He was partnered with the strongest in the group (student B), who actually was pulled through by the weaker

\begin{tabular}{|l|l|l|}
\hline Student & Least Difficult & Most Difficult \\
\hline A & Accidence & Identifying type of indirect statement \\
\hline B & Vocabulary & Tense of infinitive \\
\hline C & Vocabulary & Verb endings \\
\hline D & Vocabulary & Forming construction and noun endings \\
\hline E & Recognising the main clause & Vocabulary \\
\hline
\end{tabular}

Figure 5. What students thought was least and most difficult in prose composition exercise. 
student throughout the exercise. Student A was constantly able to explain grammar points and keep the translation on track, making him the key contributor to Group 1's good effort. In light of this, we should not forget that as a language Latin can be said to have three skills: reading, writing and speaking. Of course, as a dead language speaking is not important, but reading and writing are. It shows that while there must be a correlation between competency in one of these skills and competency in another, each skill is independent: a student may be better at one skill than the other, whether reading Latin or writing it. It would be timely to note, also, how student D's reading of indirect statements was very good, but her writing was confused and weak. There was a mistaken belief that because student A was the weakest at reading Latin, he would be the weakest at writing Latin. Therefore, to deprive any student of one of these skills is depriving him of the opportunity to a) achieve his potential academically, and, perhaps more importantly, b) enjoy his Latin as much as possible.

\section{Conclusion}

In this research I have looked at the literature on prose composition, old and recent. The value of prose composition has been the main topic of discussion, and the primary aim of learning Latin is discussed as a consequence. There seemed to be little evidence in either account and focused mainly on ideas and opinions. I aimed to investigate what it is the students think about prose composition and what they find difficult about it. It is hoped that this research provides a small amount of evidence to contribute to the discussion of prose composition and encourages more research on this in the Classical sphere. There are two things I would like to have taken from this research:

i) Reading and writing are independent skills. Regardless of the value of prose composition, a student might be good at one skill and not the other. And so, the assumption that a student who is not competent at reading Latin is not competent at writing Latin

should be quelled.

ii) The primary goal of Latin should be questioned and therefore the position of prose composition in Latin pedagogy be reconsidered. If certain aims of learning Latin can be reached by the practising of prose composition, it should be used as a tool to do so.

\section{James Eales is a teacher in a secondary school in London}

\section{Appendix A}

\section{Translation exercise from Latin into English}

Translate the following into English:

1) credo nos montem ascendere posse.

2) audivistine illos captivos effugisse?

3) femina negat se quicquam de consilio scire.

4) promisimus fore ut moenia non delerentur.

5) latronem captum esse et punitum iri scimus.

Student responses:

Student A

1) I believe it is possible to climb the mountain.

2) Did you hear those captives to have run away?

3) The woman denied herself to know anything about the plan.

4) We promised not to be going to destroy the city walls.

5) We know the thugs to have been caught and going to be punished.

Student B

1) I believe that we are able to ascend the mountain.

2) Did you hear that those captives escaped?
3) The woman denies that she knows anything about the plan.

4) We promise that the city walls will not be destroyed.

5) We know that the thug was captured and will be punished.

Student C

1) I believe that we can climb the mountain.

2) Did you hear that the captives have fled?

3) The lady denies that she knew anything about the plan.

4) We promised that the walls would not be destroyed.

5) The captured thug we know will be punished.

Student D

1) I know that we are able to climb the mountain.

2) Did you hear that those prisoners had fled?

3) The woman denies that she knows anything about the plan.

4) We promised that we would not destroy the city.

5) We think that the thug has been captured and will be killed.

Student E

1) I believe that we are able to climb the mountain.

2) Did you hear that those captives fled?

3) The girl denies that she knows anything about the plan.

4) We promised it was the case that the city walls would not be destroyed.

5) We know that the thug will be captured and punished. 


\section{Appendix B}

\section{Composition exercise from English into Latin}

Please translate the following into Latin. You should translate on alternate lines.

1) The boy said that he had found the money in the wood.

2) We think that the city is being well defended.

3) The messenger promised that the king would soon arrive.

4) The old man said that the letter had been sent previously.

5) We believe that this law is going to be changed.

Student responses:

Group 1

1) puer dixit se pecuniam in silvae invenisse.

2) putamus urbem bene defenderi.

3) nuntius promittit regem mox adventurum esse.

4) senex dixit epistulam missum esse antea.

5) credemus hoc legem mutatus iri.

Group 2

1) puer dixit se pecuniam in silva invenisse.

2) putamus urbem bene defenderi.

3) nuntius promissi fore ut rex mox advenetur.

4) senex dixit pro epistulam missum iri.

5) credemus hoc legem mutaturum.

Group 3

1) puer dixit argentum in silvam invenisse.

2) scimus urbem bene defensus esse.

3) nuntius promisit regem mox venturus esse.

4) senex dixit epistulam misus esse.

5) credimus legem changus iri.
References

Ashdowne, R. and Morwood, J. (2007). Writing Latin: An Introduction to Writing in the Language of Cicero and Caesar. Bristol: Bristol Classical Press.

Ball, R. J. and Ellsworth, J. D. (1989). Against Teaching Prose Composition in Classical Languages. Classical Journal 85, pp. 54-62.

Ball, R. J. and Ellsworth, J. D. (1992). Flushing out the Dinosaurs: Against Teaching Composition II. Classical Journal 88, pp. 55-65.

Bennett, A. (1994). Comfortable Words. In Writing Home. London: Faber \& Faber.

Bennett, C. E. and Bristol, G. P. (1903). The Teaching of Latin and Greek in the Secondary School. New York: Longmans, Green \& Co.

Butterfield, D. (2013). A Proposal for the New GCSE: Much Continuity, Some Change. Politeia 87, pp. 7-9.

Butterfield, D., Anderson, A., Radice, K., Sullivan D. (2013). Latin for Language Lovers: Ancient Languages, The New Curriculum and GCSE. Politeia, 87.

Carpenter, D. (2000). Reassessing the goal of Latin pedagogy. Classical Journal 95, pp. 391-395.

Cohen, L., Manion, L. \& Morrison, K. (2007). Research Methods in Education (6th ed). London \& New York: Routledge.

Copson, A. (2006). 'Civis sum!' Teaching Citizenship in Classics. Journal of Classical Teaching 8 .

Davisson, M. H. T. (2000). Prose Composition in Intermediate Latin: An Alternative Approach. Classical Journal 96, pp. 75-80.

Department of Education and Science (DES). (2014). Subject content and assessment objectives for GCSE in ancient languages for teaching from 2016. Retrieved 24/04/14 from https://www.gov.uk/ government/publications/gcse-ancientforeign-languages

Duckett, E. S. (1922). 'Latin Prose' and Modern Learning. CJ17, pp. 430-437.

Ecce Romani. (1984). London: Longman Publishing Group.

Fogel, J. (2002). Toward Beauty and Joy in Latin Prose Composition. Classical World 96, 79-87.
Forrest, M. (1996). Modernising the Classics. Exeter: UEP.

Forrest, M. (2003). The Abolition of Compulsory Latin and Its Consequences. Greece and Rome 50, pp. 42-66.

Gilleland, B. B. (1991). Elitist Professors and the Teaching of Prose Composition. Classical World 84, pp. 215-217.

Goodson, A. (1997). A New Way of Teaching Latin. Joint Association of Classical Teachers Review 22, pp. 7-8.

Gruber-Miller, J. (2006). Teaching Writing in Beginning Latin and Greek. In Gruber-Miller, J. (ed.), When Dead Tongues Speak. Oxford: OUP.

Harklau, L. (2002). The role of writing in Classroom Second Language Acquisition. Journal of second language writing 11, pp. 329-50.

Jacoby, R. (1994). Dogmatic Wisdom: How the Culture Wars Divert Education and Distract America. New York: Doubleday Religious Publishing Group.

Krashen, S. D. (1981). Second Language acquisition and second language learning. Oxford: Pergamon Press.

Lee, A. G. (1963). The Value of Prose Composition. Didaskalos 1.2, p. 23.

Mitchell, B. W. (1912). The Teaching of Latin Prose Composition in the Secondary School. The Classical Weekly 6, pp. 26-29.

Munn, P. \& Drever, E. (2004). Using Questionnaires in Small-Scale Research: A Beginner's Guide. Glasgow: Scottish Council for Research in Education.

Nairn, J. A. (1925). Latin Prose Composition. Cambridge: CUP.

Newman, J. K. (1990). Composition, A Reply. Classical Journal 85, pp. 334-349.

Pearcy, L. T. (1998). Writing Latin in Colleges and Schools. Classical World 92, pp. $35-42$

Postgate, J. P. (1934). Sermo Latinus: A short Guide to Latin Prose Composition. London: Macmillan And Co.

Rivers, W. M. (1981). Teaching ForeignLanguage Skills. Chicago: University of Chicago Press.

Sapsford and Abbott (1996) Ethics, Politics and Research. In Sapsford, R. and Jupp, V. (eds). Data Collection and Analysis. London: Sage. 
Saunders, A. L. (1993). The Value of Latin Prose Taylor, J. (2009). Latin Beyond GCSE. Bristol: Composition. Classical Journal 88, pp. 385-392.

Sharwood Smith, J. (1977). On Teaching Classics. Routledge \& Kegan Paul.

Stray, C. (2003). Classics in the curriculum up to the 1960s. In Morwood, J. (ed.) The Teaching of Classics. Cambridge CUP. BCP.

Taylor, J. (2003). Greek, to GCSE: Part 1. Bristol: BCP.

The Classical Investigation (Part I): General Report. (1924). Princeton: Princeton

University Press.
Wilson, E. (2009). School-based Research: A Guide for Education Students. London: SAGE Publications.

Yin, R. (2003). Case Study Research: Design and Methods (3rd Edition). Beverly Hills, CA: Sage Publishing. 